\title{
Dual-Color High-Resolution Fiber-FISH Analysis on Lethal White Syndrome Carriers in Sheep
}

\author{
A. Pauciullo ${ }^{a}$ K. Fleck ${ }^{a}$ G. Lühken ${ }^{a}$ D. Di Berardino ${ }^{\text {b }}$ G. Erhardt ${ }^{a}$

 \\ Environment and Animal Production Science, University of Naples Federico II, Portici, Italy
}

\section{Key Words}

Breakpoints · Chromatin fibers · EDNRB · Fluorescence in situ hybridization $\cdot$ Lethal white syndrome $\cdot$ Sheep

\begin{abstract}
Molecular defects occurring in the endothelin receptor type$\mathrm{B}$ (EDNRB) gene are known to be associated with pigmentary anomalies and intestinal aganglionosis in humans, rodents and horses. We carried out a cytogenetic investigation in 2 ewes heterozygous for the deletion of the EDNRB gene and in 2 more females as control. The RBA-banding showed that all 4 ewes were karyologically normal. EDNRB gene-specific probes were produced by PCR and cloning. The application of the R-banding and propidium iodide-staining fluorescent in situ hybridization allowed mapping the gene to OAR 10q22 and confirmed the heterozygous status of the ewes investigated for the EDNRB gene deletion. For the fine estimation of the gene length in sheep and for the correct sizing of the chromosomal gap, a dual-color FISH was applied to high-resolution DNA fibers in combination with digital imaging microscopy. The comparison of the DNA fiber barcodes indicated a chromosomal deletion larger than the EDNRB gene itself. The length of the gene, not known for sheep until now, was estimated to be $\sim 21 \mathrm{~kb}$, whereas the microchromosomal deletion was $\sim 100 \mathrm{~kb}$. EDNRB is located
\end{abstract}

in a chromosomal region previously shown to be a fragile site. The applied method allowed locating the potential breakpoints, thus permitting further interesting prospective investigations also in the field of the fragile sites in sheep.

Copyright $\odot 2013$ S. Karger AG, Basel

Migration, proliferation and differentiation of neural crest cells are fundamental stages for the arrangement of a functional enteric nervous system. Their breakdown results in an intestinal region characterized by the absence of enteric neurons along varying lengths of the colon (aganglionic zone). As enteric neurons are indispensable for gut motility, the aganglionic region remains tonically constricted, hampering the movement of faecal material [Wallace and Anderson, 2011]. In humans, this condition is also known as Hirschsprung's disease (HD), a particular type of the Waardenburg syndrome characterized by the association of pigmentation abnormalities and aganglionic megacolon [Omenn and McKusick, 1979; Shah et al., 1981; Badner and Chakravarti, 1990; Bonnet et al., 1996] which occurs in approximately 1:5,000 live births [Amiel et al., 2008].

Humans are not the only mammals to suffer from aganglionosis. Lethal white foal syndrome (LWFS) of Paint horses is an autosomally inherited condition of

\section{KARGER}

(C) 2013 S. Karger AG, Basel

$1424-8581 / 13 / 1401-0046 \$ 38.00 / 0$

E-Mail karger@karger.com

www.karger.com/cgr
Alfredo Pauciullo, PhD

Institute of Animal Breeding and Genetics, Justus-Liebig University

Ludwigstrasse $21 \mathrm{~b}$

DE-35390 Giessen (Germany)

E-Mail alfredo.pauciullo@ agrar.uni-giessen.de 
newborn foals born to parents of the overo lineage [Trommershausen-Smith, 1977; Schneider and Leipold, 1978]. The foals are totally or almost totally white and are affected by intestinal aganglionosis [Hultgren, 1982; Vonderfecht et al., 1983; McCabe et al., 1990].

The molecular event responsible for the LWFS in American [Metallinos et al., 1998; Santschi et al., 1998] and Australian [Yang et al., 1998] Paint horses is a dinucleotide exchange in the endothelin type- $\mathrm{B}$ receptor gene (EDNRB).

The EDNRB gene is known to be involved in the developmental regulation of neural crest cells that become enteric ganglia and melanocytes. It was mapped to chromosome 13q22 in human [Arai et al., 1993], chromosome12q22 in cattle [Schläpfer et al., 1997] and to chromosome 10q22 in sheep [Iannuzzi et al., 2001].

In mice, mutations in the $E d n r b$ gene are responsible for disorders associated with the white coat spotting and intestinal aganglionosis [Hosoda et al., 1994; Ceccherini et al., 1995].

A hypopigmented phenotype and signs of intestinal obstruction similar to aganglionosis reminiscent of the LWFS occurred also in sheep. The deletion of the entire $E D N R B$ gene in sheep was shown to be the cause of the observed phenotype [Lühken et al., 2012; Pauciullo et al., 2012a]. However, in sheep the lack of a complete DNA sequence allowed the authors only to estimate the gap as comparison to the homologous bovine sequence. Hence, further investigation is necessary to clarify the length of the deletion.

High-resolution fiber FISH is a method which allows the direct visualization of DNA sequences along the chromatin fibers released from interphase nuclei [Fidlerova et al., 1994], and it is often used for resolving size-gapping problems [Florijn et al., 1995]. Recently, this technique was also used to visualize allele-specific gene copy number variation and orientation by using specific probes [Perry et al., 2007].

The aim of this study was to provide further cytogenetic information on the ovine EDNRB gene by using FISH with a set of specific probes in order to determine the size of the chromosomal deletion and to estimate the length of the gene in the sheep.

\section{Material and Methods}

\section{Animals}

Five completely white-coated lambs with blue eyes were born in a small group of Cameroon sheep, where only one ram was used for several consecutive years and mated to his relatives. All white- coated lambs died shortly after birth. Cytogenetic investigations were carried out on 2 ewes, both previously found to be heterozygous carriers of a gene deletion $\left(E D N R B^{+/-}\right)$[Lühken et al., 2012]. Two normal ewes $\left(E D N R B^{+/+}\right)$belonging to the same flock were used as controls.

\section{Karyotyping of the Samples}

Peripheral blood cell cultures from the investigated animals were treated for conventional and late-incorporation of BrdU (15 $\mu \mathrm{g} / \mathrm{ml})$ to obtain R-banding preparations. Hoechst 33258 (30 $\mu \mathrm{g} /$ $\mathrm{ml}$ ) was simultaneously added to BrdU $6 \mathrm{~h}$ before harvesting to enhance the R-banding patterns. The sheep were karyotyped according to standard methods [Iannuzzi and Di Berardino, 2008] for RBA-banding techniques. Chromosome identification followed the R-banded standard ideogram according to the latest international nomenclature for domestic bovids chromosomes [ISCNDB, 2000]. The conventional and R-banding preparations were further used for FISH analysis.

\section{Chromatin Fiber Preparation}

Chromatin fibers (fig. 1a) were prepared according to the method described by Fidlerova et al. [1994] with minor modifications. In brief, lymphocyte cells spread on the slides were quickly transferred to a coplin jar containing $1 \times$ PBS for 70 s and gently stretched $3 \times$ with the edge of a coverslip by using $100 \mu \mathrm{l}$ of $0.1 \mathrm{~N} \mathrm{NaOH}: 100 \%$ ethanol (5:2). After sodium hydroxide treatment, 2 drops of the classical methanol-acetic acid (3:1) fixative were applied to the slides to improve the reproducibility of the release technique. Slides were dried at room temperature and dehydrated sequentially at room temperature for 2 min each with 70 and $95 \%$ ethanol.

\section{Probes Preparation}

The EDNRB gene probes were prepared by PCR amplification of 3 DNA fragments spread over the gene itself and one DNA fragment directly upstream the $E D N R B$ gene (primers are provided in table 1). The PCR reaction mix $(50 \mu \mathrm{l})$ comprised: $100 \mathrm{ng}$ of genomic DNA, $1 \times$ GeneAmp PCR Buffer II (Applied Biosystems, Germany), $2 \mathrm{~mm} \mathrm{MgCl} 2,2 \mathrm{pmol}$ of each primer, dNTPs each at $200 \mu \mathrm{M}, 2.5 \mathrm{U}$ of AmpliTaq ${ }^{\circledR}$ DNA Polymerase (Applied Biosystems). PCR was performed under the following conditions: $95^{\circ} \mathrm{C}$ for $4 \mathrm{~min}, 35 \mathrm{cycles}$ at $95^{\circ} \mathrm{C}$ for $1 \mathrm{~min}, 60^{\circ} \mathrm{C}$ for $45 \mathrm{~s}, 72^{\circ} \mathrm{C}$ for $2 \mathrm{~min}$, with the final extension at $72^{\circ} \mathrm{C}$ for $10 \mathrm{~min}$. All the amplified fragments were analyzed by electrophoresis on $1.5 \%$ agarose gels in $0.5 \times$ TBE buffer and stained with ethidium bromide (fig. 1b).

PCR products were purified by Invisorb ${ }^{\circledR}$ Fragment Cleanup kit (Invitek, Germany) and cloned using the pGEM $^{\circledR}$-T Easy Vector System (Promega, Madison, Wisc., USA). White recombinant clones were randomly chosen and screened by PCR using standard vector primers M13. Recombinant clones underwent plasmid purification by PureYield ${ }^{\mathrm{TM}}$ Plasmid Midiprep System (Promega) and then sequencing reaction using the BigDye ${ }^{\circledR}$ Terminator Sequencing kit (Applied Biosystems). Sequencing was accomplished using an ABI 3130 Genetic Analyzer (Applied Biosystems). Approximately $1.5 \mu \mathrm{g}$ of each purified plasmid was labeled with biotin-16-dUTP by standard nick translation (Roche, Germany) and then used for FISH analysis.

NCBI clone finder resource (http://www.ncbi.nlm.nih.gov/ clone/) was used to choose a BAC clone. The ovine genomic $E D N R B$ sequence available via the sheep chromosome sequence v1.0 (http://www.livestockgenomics.csiro.au/sheep/oar1.0.php) 


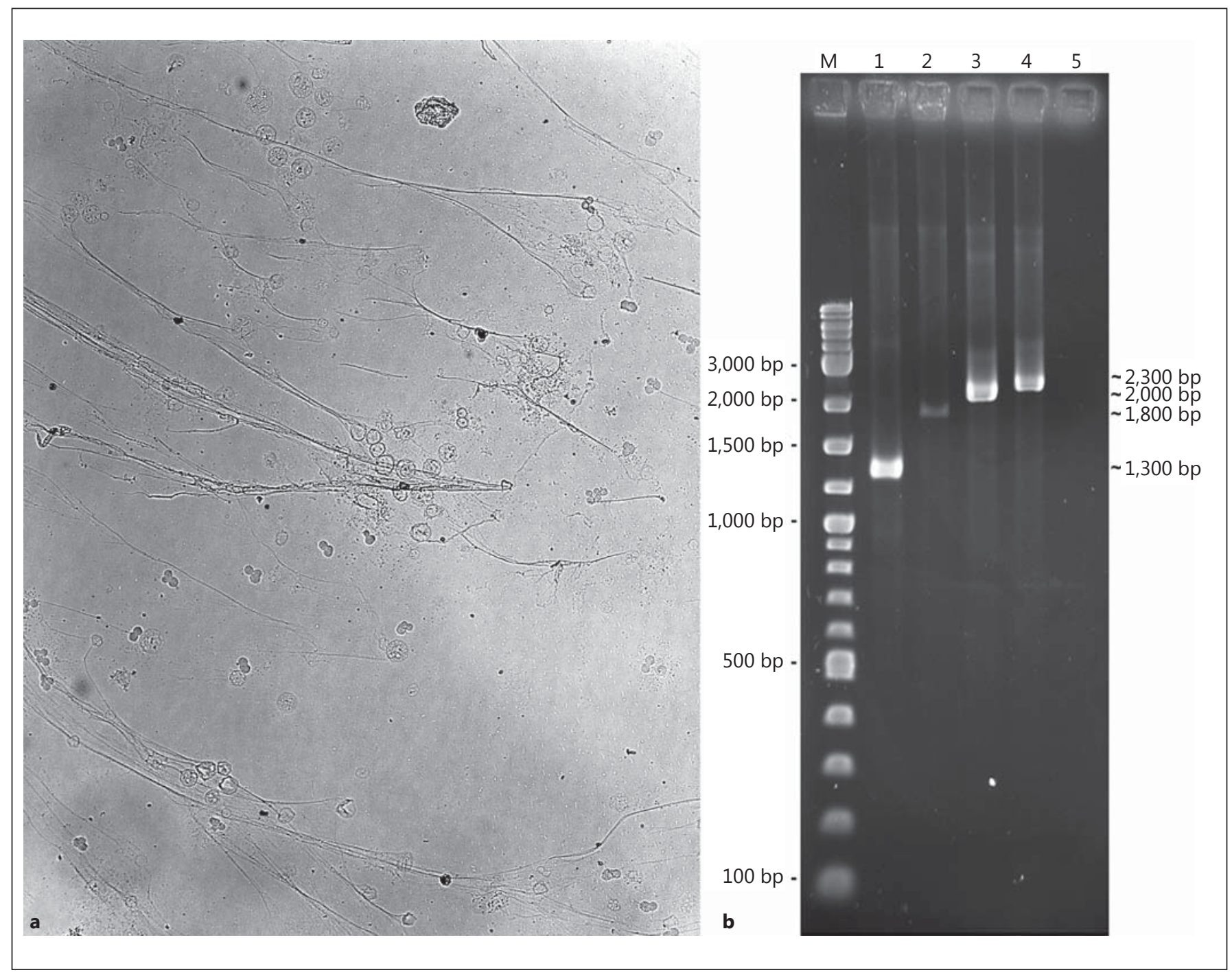

Fig. 1. a Chromatin fibers released from fixed lymphocyte cells (magnification $20 \times$ ). b PCR amplification of specific DNA probes belonging to $E D N R B$ gene in sheep. Line 1: promoter region and partial exon $1(\sim 1,300 \mathrm{bp})$; line 2 : partial intron $1(\sim 1,800 \mathrm{bp})$; line

was not annotated and exhibited many gaps. The ambiguous localization of the available BACs in the sheep led us to prefer the bovine clone $\mathrm{CH} 240-51 \mathrm{D} 6$, reported in NCBI web site as tested and precisely mapped to chromosome 12q22 in cattle. The clone was purchased from the BAC/PAC collection belonging to Children's Hospital Oakland Research Institute (CHORI, Oakland, Calif., USA).

BAC DNA isolation was carried out according to the alkaline lysis miniprep protocol suggested by CHORI. Before the labeling, the DNA was tested via PCR for the EDNRB locus using the following primers: $5^{\prime}$-GAAGATTATTCCTTGATGAGCATTT-3' (forward) and $5^{\prime}$-CAGACTAAGAAAAAGGAATTATGCTCT- ${ }^{\prime}$ (reverse) and the same chemical condition aforementioned. The amplified fragment (366 bp) spans over the exon 4 (data not shown).
3: probe covering the DNA region between exon 2 and exon 4 $(\sim 2,000 \mathrm{bp})$; line 4: probe covering the DNA region between intron 5 and exon 7 ( 2,300 bp); M: 2-log DNA ladder 0.1-10 kb (New England Biolabs, Mass., USA).

Approximately $1.5 \mu \mathrm{g}$ of BAC DNA was combined with $20 \mu \mathrm{l}$ $2.5 \times$ random primer (BioPrime aCGH Labeling Module, Invitrogen, Germany) in a total volume of $39 \mu \mathrm{l}$. Samples were incubated at $95^{\circ} \mathrm{C}$ for $5 \mathrm{~min}$ and were then placed on ice for $5 \mathrm{~min}$. Next, $5 \mu \mathrm{l} 10 \times$ dUTP, $1 \mu \mathrm{l}$ Exo-Klenow Fragment (BioPrime Module) and $5 \mu \mathrm{l}(0.6 \mathrm{~mm})$ DIG-11-dUTP (Roche) were added. Samples were incubated at $37^{\circ} \mathrm{C}$ for $5 \mathrm{~h}$ and then used for in situ hybridization.

\section{FISH}

R-banding by late BrdU-incorporation and propidium iodidestaining FISH (RPBI-FISH) was performed according to Iannuzzi and Di Berardino [2008], whereas fiber FISH and conventional FISH were performed according to Pauciullo et al. [2012b] with minor modifications. Briefly, for each experiment, $500 \mathrm{ng}$ of each 
Table 1. Primer sequences and amplicon size used for the preparation of the probes covering the EDNRB gene in Ovis aries

\begin{tabular}{|c|c|c|c|c|}
\hline Amplicon & Physical location & Primers & Sequence & Size \\
\hline 1 & promoter-exon 1 & $\begin{array}{l}\text { forward }^{\mathrm{a}} \\
\text { reverse }\end{array}$ & $\begin{array}{l}5^{\prime} \text {-GAGGTAACCGTTCTGCTT-3' } \\
5^{\prime} \text {-GGCTGGCTATCAAGATATTT-3' }\end{array}$ & $\sim 1,300 \mathrm{bp}$ \\
\hline 2 & intron 1 & $\begin{array}{l}\text { forward }^{b} \\
\text { reverse }^{b}\end{array}$ & $\begin{array}{l}5^{\prime} \text {-AAAATGCTGGTATGTCAAAATG-3' } \\
5^{\prime} \text {-TAGCATTAGGCATGTTTCT-3' }\end{array}$ & $\sim 1,800 \mathrm{bp}$ \\
\hline 3 & exon 2-exon 4 & $\begin{array}{l}\text { forward } \\
\text { reverse }\end{array}$ & $\begin{array}{l}5^{\prime} \text {-GAGATGTGTAAGCTGGTG-3' } \\
5^{\prime} \text {-CAATTTGCATACCACTCTTCT-3' }\end{array}$ & $\sim 2,000 \mathrm{bp}$ \\
\hline 4 & intron 5 -exon 7 & $\begin{array}{l}\text { forward }^{\mathrm{b}} \\
\text { reverse }\end{array}$ & $\begin{array}{l}5^{\prime} \text {-GAGAGAGACAGAAGCAAAGAGAAA-3' } \\
5^{\prime} \text {-TCAAGATGAGCTGTATTTATTAC-3 }\end{array}$ & $\sim 2,300 \mathrm{bp}$ \\
\hline
\end{tabular}

\footnotetext{
${ }^{a}$ Designed on bovine EDNRB promoter region (EMBL acc. No. D10994).

${ }^{\mathrm{b}}$ Designed on bovine EDNRB gene (EMBL acc. No. NC_007310). The other primers were designed on sheep EDNRB gene sequence (GenBank acc. No. JQ937242).
}

labeled DNA probe (BAC probe plus 4 EDNRB probes) were mixed together and combined with $5 \mu \mathrm{g}$ of salmon sperm DNA and $10 \mu \mathrm{g}$ of calf thymus DNA. This mixture was precipitated in ethanol $100 \%$, air-dried and then reconstituted in $7 \mu$ hybridization solution ( $50 \%$ formamide in $2 \times$ SSC $+10 \%$ dextran sulfate), denatured at $75^{\circ} \mathrm{C}$ for $10 \mathrm{~min}$, and incubated at $37^{\circ} \mathrm{C}$ for $60 \mathrm{~min}$.

The slides were denatured for $3 \mathrm{~min}$ in a solution of $70 \%$ formamide in $2 \times \mathrm{SSC}(\mathrm{pH} 7.0)$ at $75^{\circ} \mathrm{C}$.

The hybridization mixture was applied to the slides, covered with $24 \times 24 \mathrm{~mm}$ coverslips and incubated in a moist chamber at $37^{\circ} \mathrm{C}$ overnight. After hybridization, the slides were washed in: $2 \times$ SSC at room temperature for $1 \mathrm{~min}, 0.4 \times \mathrm{SSC}+0.3 \%$ Nonidet P40 (Applichem, Germany) at $73^{\circ} \mathrm{C}$ for $2 \mathrm{~min}, 2 \times \mathrm{SSC}$ at room temperature for $1 \mathrm{~min}$. Slides were then incubated with $75 \mu \mathrm{l} 1 \times$ hybridization blocking solution (Vector Laboratories, Burlingame, Calif., USA) for $30 \mathrm{~min}$ at room temperature.

Detection steps were carried out with 1:400 fluorescein isothiocyanate-avidin (Vector Laboratories) and 1:200 anti-avidin antibody (Vector Laboratories) for the biotin-labeled probe (green signal), whereas the digoxigenin-labeled probe (red) was detected using 1:400 rhodamine fluorochrome conjugated to an anti-digoxigenin antibody from sheep (Roche). Three-step detection and signal amplification were used for RPBI and chromatin fiber slides. Each step was conducted for $45 \mathrm{~min}$ at room temperature followed by 3 washes in $1 \times$ PBT for 5 min each at room temperature by gently shaking.

R-banding slides were mounted with Antifade/Propidium Iodide $(3 \mu \mathrm{g} / \mathrm{ml})$, conventional slides were counterstained with DAPI $(0.24 \mu \mathrm{g} / \mathrm{ml})$ (Sigma, St. Louis, Mo., USA) in Antifade (Vector Laboratories), whereas chromatin fibers were mounted with Antifade only.

\section{Fluorescence Analysis and Scoring}

The slides were observed at $100 \times$ magnification with an AX70 Olympus (Olympus Deuschland $\mathrm{GmbH}$, Germany) fluorescence microscope equipped with DAPI, fluorescein isothiocyanate and

Fiber-FISH Analysis on Lethal White Syndrome in Sheep
Texas Red-specific filters. Digital images were captured using the CellP software ver. 2.6.

A total of 30 randomly selected metaphase cells were examined per normal control to ensure the reliability of the probe signals by FISH. The hybridization efficiency was calculated as follows: FISH efficiency (\%) is equal to the number of cells with hybridization signals present at the $10 \mathrm{q} 22$ region of both chromosomes $10 \mathrm{di}-$ vided by the number of cells examined. Distances between the probe signals were computed and further analyzed in a spreadsheet program according to Florijn et al. [1995].

\section{Results}

The 4 investigated sheep were karyotyped. The analysis of the RBA-banding pattern showed karyologically normal animals. Sheep chromosome 10 is reported in detail in figure $2 \mathrm{a}$.

\section{High-Resolution FISH}

Four PCR amplicons spanning the EDNRB gene and partially its promoter region were mixed together and used to set up a FISH method for the detection of the gene deletion. The specificity of the amplified probes was first verified by agarose gel electrophoresis (fig. 1b) and then by sequencing the corresponding recombinant clones for approximately $500 \mathrm{bp}$ in each direction. The comparison with the homologous bovine sequence (EMBL acc. No. NC_007310) confirmed that the probes belonged to the EDNRB gene (table 1).

To ensure the reliability of the detection of the gene signals by FISH, the probes were preliminarily tested on 



Fig. 2. FISH obtained by using specific EDNRB gene probes on sheep metaphases shows specific signal on OAR chromosome 10q2.2. a Diagrammatic representation of OAR 10, RBA-banding, RBPI and DAPI staining. b Heterozygous sample for $E D N R B$ gene deletion (DAPI staining). c Heterozygous sample for $E D N R B$ gene deletion (RBPI staining). d Normal sheep sample. Fluorescein isothiocyanate signals were superimposed on RBPI-banding (Rbanding using early BrdU-incorporation and propidium iodide staining).
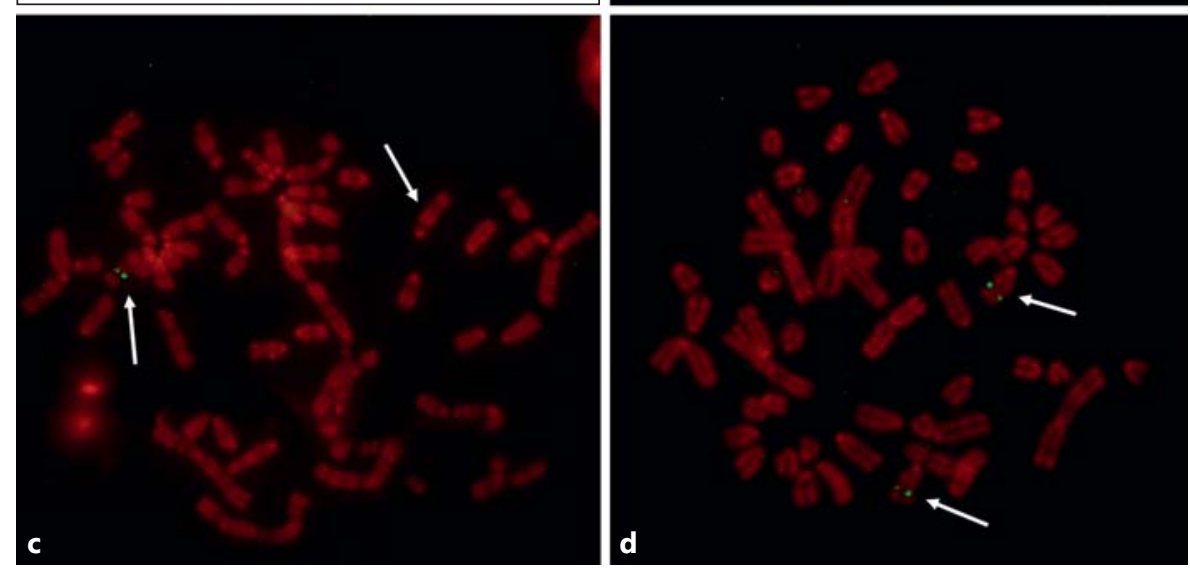

the 2 normal individuals $\left(E D N R B^{+/+}\right)$; then the probes were applied to the heterozygous EDNRB deleted samples. For all the analyzed samples, the FISH efficiency was $91 \%$ on average (range $83-95 \%$ ).

DAPI counterstained FISH analysis on heterozygous gene-deleted animals showed 2 symmetrical spots on a single chromosome (fig. 2b), whereas the normal samples showed 4 distinct signals on the 2 homologous chromosomes. In the RBPI-FISH experiment, the EDNRB gene showed 2 symmetrical spots located on the chromosome 10q2.2 (fig. 2a), according to the standard ideogram. For the 2 investigated sheep $\left(E D N R B^{+-}\right)$, the hybridization signal was visible only on one chromosome 10 , whereas no signal was detected on the other homologous chromosome 10 (fig. 2c). In the normal sample $\left(E D N R B^{+/+}\right)$, however, 2 clearly visible spots were detected on both chromosomes 10 (fig. 2d). This finding confirmed that the deletion is located on chromosome 10q2.2 and that the 2 investigated ewes are heterozygous carriers of the $E D N R B$ gene deletion.

\section{Fiber FISH}

In order to estimate the length of the gene, the size of the gap and its position, we set up a dual-color high-resolution fiber-FISH analysis. A bovine BAC probe, including the $E D N R B$ gene, was used in a ZOO-FISH experiment to cover approximately $200 \mathrm{~kb}$ of OAR 10q2.2. The $\mathrm{BAC}$ was labeled in red, whereas a mixture of 4 specific sheep $E D N R B$ gene probes was labeled in green.

According to the length of the chromatin fiber, 4 distinct green spots (on average) were visible for the $E D N R B$ gene probes for the normal chromosome, whereas no signal was detected on the homologous EDNRB deleted chromosome (fig. 3a, b). Overlapping colors between BAC and EDNRB gene probes often resulted in yellow signals (fig. 3b).

The comparison of the fiber barcodes from the homologous chromosomes indicated the physical location of the breakpoints and a deletion even larger than the $E D N R B$ gene itself. The analysis of the distance between the spots allowed us to estimate the length of the gene in 

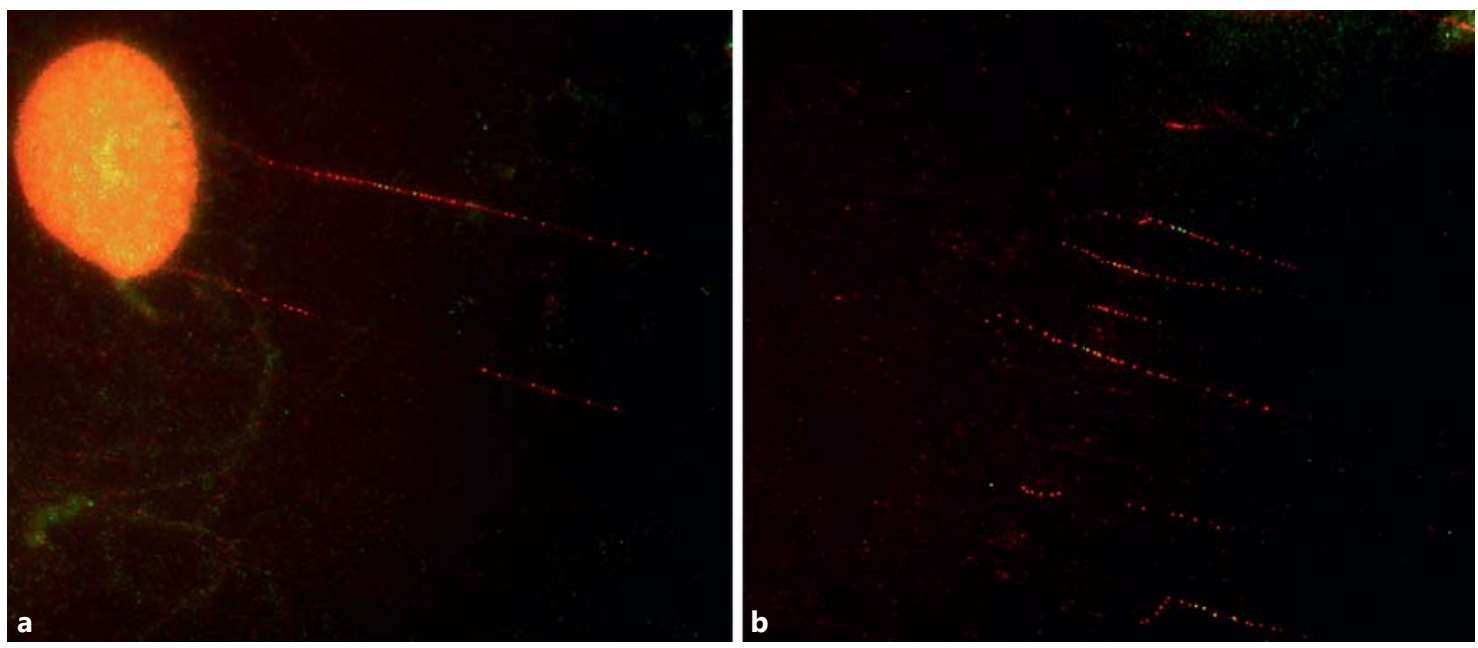

Fig. 3. Fiber-FISH mapping of the EDNRB gene. a High-resolution fibers flowing out of a lymphocyte cell of sheep heterozygous for a chromosomal deletion of about $100 \mathrm{~kb}$. The BAC probe is in red $(\sim 200 \mathrm{~kb})$ and the EDNRB gene-specific probes are in green $(\sim 21$ $\mathrm{kb})$. The alignment among the spots of the 2 fibers (color barcode)

the sheep to be about $21 \mathrm{~kb}$, whereas the length of the entire microchromosomal deletion was calculated to be approximately $100 \mathrm{~kb}$ (table 2 and fig. 4 ).

\section{Discussion}

The mating of genetically related animals is known to increase the homozygosity. Such condition can also increase the chances of offspring to be affected by recessive traits. In this study, we carried out a cytogenetic investigation on 2 ewes belonging to a small flock of Cameroon sheep, mated to their father, which produced hypopigmentated lambs with clinical signs similar to the LWFS.

For the first time, we produced DNA clones specific for the sheep EDNRB gene and hybridized them to metaphase chromosomes of cultured lymphocytes in experiments of high-resolution FISH. The 2 ewes were heterozygous for the deletion of the entire EDNRB gene. The specific signals were located only on one of the homologous chromosomes demonstrating the presence of a single copy of the gene (fig. 2b). Since the DAPI banding does not allow chromosome identification, we set up a RPBI-FISH experiment to physically map the EDNRB gene. With this method, it is possible, in fact, to visualize simultaneous Rbanding (by late BrdU-incorporation and propidium iodide staining) and fluorescein isothiocyanate signals (by the specific probes) providing immediate and clearer re-

Fiber-FISH Analysis on Lethal White Syndrome in Sheep occurred naturally during the stretching and normalization was not necessary. $\mathbf{b}$ Bundle of chromatin fibers with and without specific green signals for the EDNRB gene. Overlapping of colors between BAC and gene probes often resulted in yellow signals according to the degree of decondensation of the fibers.

Table 2. Singles and average values of the chromosomal deletion and the EDNRB gene length

\begin{tabular}{lrlll}
\hline Measurement & $\begin{array}{l}\text { Deletion } \\
\mathrm{kb}\end{array}$ & $\mathrm{SE}$ & $\begin{array}{l}\text { EDNRB gene SE } \\
\mathrm{kb}\end{array}$ \\
\hline 1 & 97,638 & & 20,472 & \\
2 & 98,462 & & 21,538 & \\
3 & 101,695 & & 20,339 & \\
4 & 94,949 & & 24,242 & \\
5 & 97,561 & 0.849 & 19,512 & 0.509 \\
6 & 103,636 & & 21,818 & \\
7 & 97,561 & & 22,748 & \\
8 & 96,098 & & 21,951 & \\
9 & 99,048 & & 20,952 & \\
10 & 101,333 & & 18,667 & \\
Average & 98,798 & & 21,226 & \\
\end{tabular}

Estimated out of 10 fibers normalized for the degree of DNA condensation and computed according to Florijn et al. [1995].

$\mathrm{SE}=$ Standard error.

sults. According to the standard ideogram, the position of the EDNRB gene was confirmed on chromosome 10q2.2 (fig. 2a), while the 2 investigated ewes were confirmed to be heterozygous carriers of the EDNRB gene deletion (fig. 2c), according to the molecular assessment reported by Lühken et al. [2012] and the preliminary cytogenetic analysis stated by Pauciullo et al. [2012a]. 


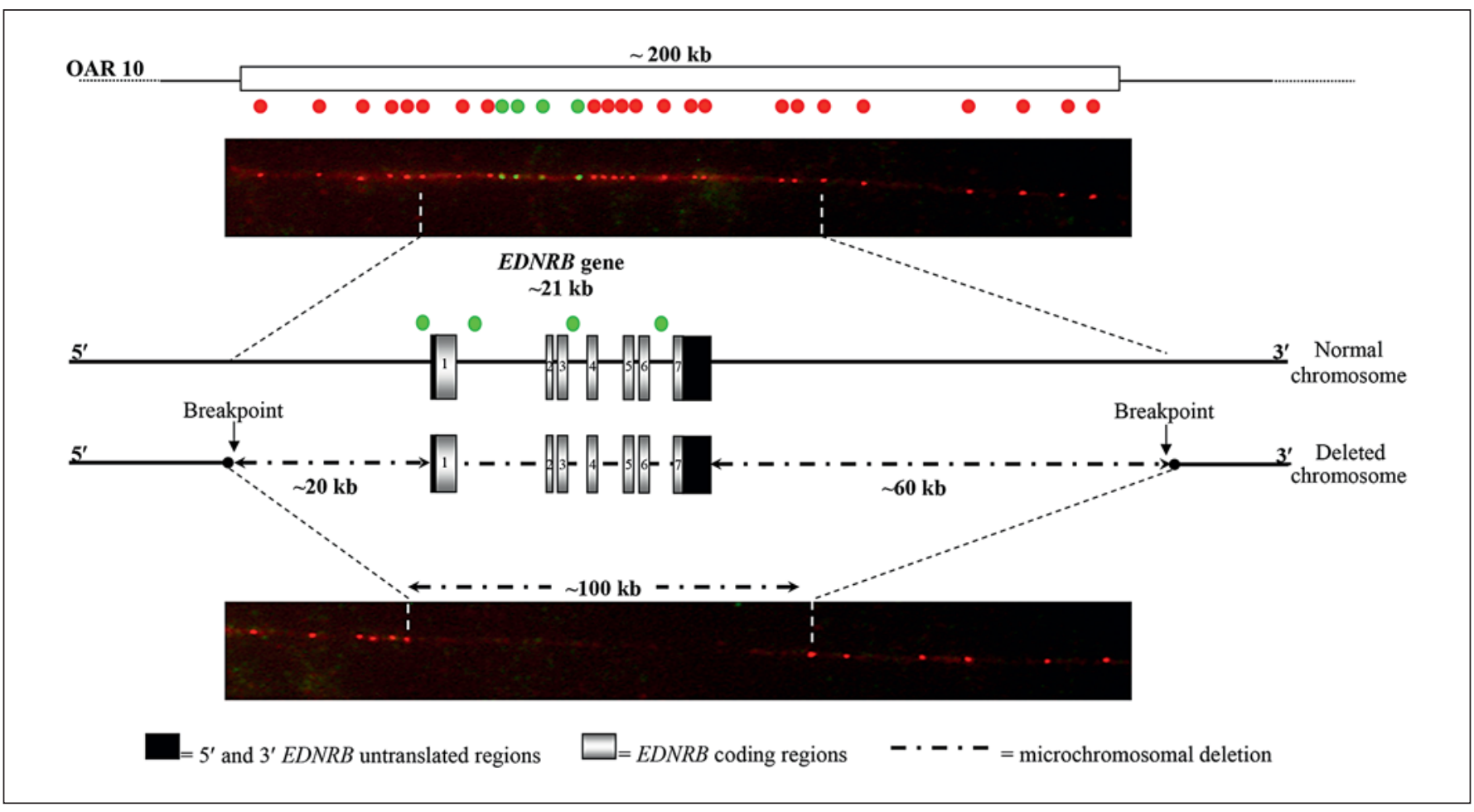

Fig. 4. FISH on the homologous chromatin fibers of the sheep chromosome 10 (OAR 10) for the heterozygous carrier of the microchromosomal deletion and schematic representation of the genetic defect. The BAC probe is in red $(\sim 200 \mathrm{~kb})$ and the EDNRB gene-specific probes are in green $(\sim 21 \mathrm{~kb})$. Dashes indicate the deleted fragment of about $100 \mathrm{~kb}$ including the EDNRB gene.

The deletion of the EDNRB locus is a molecular event occurring also in other species. For instance in human, Lamont et al. [1989] reported 2 patients with multiple congenital anomalies/mental retardation syndromes whose findings included HD. The chromosomal aberration was interpreted as $\operatorname{del}(13)(\mathrm{q} 14.1 \mathrm{q} 22.3)$, which includes the EDNRB locus. The same chromosome was found to be deleted in another clinical case of HD by Bottani et al. [1991]. Deletions of the distal long arm of human chromosome 13 were more recently investigated by high-resolution comparative genomic hybridization, and the Waardenburg-Shah syndrome (a disorder which combines the manifestation of Waardenburg syndrome and $\mathrm{HD}$ ) has also been mapped to the EDNRB locus [Shanske et al., 2001].

The total whiteness and megacolon associated with a naturally occurring deletion of the complete Ednrb locus in homozygous piebald-lethal mice is quite similar to the phenotype caused by a targeted disruption of the gene in Ednrb knock-out mice [Hosoda et al., 1994]. A deletion of $301 \mathrm{bp}$, spanning from the distal half of the second exon to the proximal part of the adjacent intron of the Ednrb gene, results in the absence of a functional receptor protein in the spotted lethal rat [Gariepy et al., 1996].

Different is the case of LWFS in horse. In fact, this variant of HD is associated to missense mutations in the endothelin-B receptor gene [Yang et al., 1998; Metallinos et al., 1998], and no cases of chromosomal deletions were reported so far.

Since in all the aforementioned cases, no high-resolution investigation was performed, we decided to combine the use of $E D N R B$-specific probes with a bovine BAC probe in order to develop a dual-color high-resolution fiber-FISH method which would allow us to estimate the size of the chromosomal deletion in the 2 ewes heterozygous carriers and the length of the EDNRB gene in normal sheep.

This approach was chosen because chromatin fibers are much less condensed in the interphase nucleus; moreover, since fibers are stretched out linearly on a microscope slide, the order of the genes can be maintained [Heng and Tsui, 1998]. Furthermore, Florijn et al. [1995] 
demonstrated that the availability of fiber-FISH dual-color barcodes allows the rapid visual identification of gene rearrangements such as deletions, translocations or duplications, due to the identification of the breakpoints in clinical DNA samples.

In the investigated sheep, the application of a dualcolor fiber FISH and the comparison of the generated barcode allowed the identification of chromosomal breakpoints and the detection of an interstitial deletion of about $100 \mathrm{~kb}$ on chromosome 10, including the entire $E D N R B$ gene (fig. 4). Although the degree of condensation of the hybridization tracks may vary by a factor of $\sim 1.8$, the normalized average fiber-FISH lengths were found to be fairly accurate with a standard error of 0.849 out of 10 measurements (table 2). Our estimation of the chromosomal deletion $(\sim 100 \mathrm{~kb})$ is slightly lower $(\sim 10$ $\mathrm{kb})$ than the finding of Lühken et al. [2012]; however, the order of magnitude of the microchromosomal deletion is the same.

The average length of the $E D N R B$ gene was estimated to be $\sim 21 \mathrm{~kb}$ (table 2 and fig. 4). A confirmation of the assessed size was found also in the virtual sheep genome browser ver. 1.2.1 (http://www.livestockgenomics.csiro. $\mathrm{au} /$ perl/gbrowse.cgi/vsheep1.2/). This size is similar to the horse EDNRB gene $(\sim 21 \mathrm{~kb}, \mathrm{EMBL}$ acc. No. NC_009160), but it seems to be shorter than the homologous gene in human ( $~ 80 \mathrm{~kb}$, EMBL acc.No.NG_011630), mouse ( $29 \mathrm{~kb}$, EMBL acc. No. AC_000036) and bovine ( $33 \mathrm{~kb}$, EMBL acc. No. NC_007310). However, this result is not surprising. It is in fact known that the lengths of intergenic regions and genes can vary even among closely related species, as in the case of the ruminants. An example is given by casein genes, where the bovine CSN1S1 locus is bigger than the caprine counterpart as a consequence of retrotransposon insertions [Ramunno et al., 2004].

The orientation of the EDNRB gene along the fibers was not defined with certainty, but considering the structure of the gene and the physical location of the probes, it is more likely that a large part of the deletion belongs to the $3^{\prime}$-flanking region $(\sim 60 \mathrm{~kb})$, whereas the $5^{\prime}$-flanking region of the gene is missing only by a length of $\sim 20 \mathrm{~kb}$ (fig. 4).

These results agree with the molecular data reported by Lühken et al. [2012]. These authors used the bovine genomic sequence (EMBL acc. No. NC_007310.4) as reference to estimate the chromosomal deletion of the lambs affected by hypopigmentation. However, the comparison of sequences belonging to different species is theoretically not adequate for a precise evaluation of molecular dif- ferences. Due to the lack of a complete available sequence and the presence of many gaps also in the recent update of the sheep genome (http://www.livestockgenomics. csiro.au/sheep/oar3.1.php), the approach we used in the present study can be considered as definitely useful and precise.

To our knowledge, this is the first time that a deletion of the entire $E D N R B$ locus has been described by fiber FISH. The high-resolution method developed in this study provides simple, rapid and precise detection of the chromosomal gap. Furthermore, the evaluation of the size of the break can be considered definite in sheep.

It is also interesting to note that the EDNRB gene is mapped in a chromosomal region considered as a fragile site, both in sheep [Ali et al., 2008] and in river buffalo [Nicodemo et al., 2008]. Although the location and the distribution of fragile sites are species-specific, their cytogenetic expression is a consequence of genome instability at specific loci, then involved in chromosome breakage and recombination events [Svetlova et al., 2001]. Chromosomal regions carrying evolutionary important genes should be less prone to break than others [Nicodemo et al., 2008]. However, it is not possible to exclude that in sheep the deletion including EDNRB gene might be generated by an abnormal recombination event or by a chromosomal breakage, thus, opening further interesting perspectives of investigation also in the field of the fragile sites in sheep.

\section{Acknowledgements}

We are grateful to Svatava Kubickova (Department of Genetics and Reproduction, Veterinary Research Institute, Czech Republic) for the precious information in the preparation of specific gene probes, and Giulia Pia Di Meo (ISPAAM, Laboratory of Animal Cytogenetics and Gene Mapping, National Research Council, Italy) for the suggestion in the preparation of chromatin fibers. We would also like to thank Pietro Parma (Department of Animal Science, University of Milan, Italy) for providing useful information on the choice of the BAC clone, and Donato Penninella, David Hinchliffe (Biotechnology Center, University of Giessen, Germany) and Daniela Ott (Institute for Animal Physiology, University of Giessen, Germany) for the excellent technical assistance in the use of the fluorescence microscope. 


\section{References}

Ali A, Abdullah M, Babar ME, Javed K, Nadeem A: Expression and identification of folatesensitive fragile sites in British Suffolk sheep (Ovis aries). J Genet 87:219-227 (2008).

-Amiel J, Sproat-Emison E, Garcia-Barcelo M, Lantieri F, Burzynski G, et al: Hirschsprung disease, associated syndromes and genetics: a review. J Med Genet 45:1-14 (2008).

-Arai H, Nakao K, Takaya K, Hosoda K, Ogawa Y, et al: The human endothelin-B receptor gene: structural organization and chromosomal assignment. J Biol Chem 268:3463-3470 (1993).

- Badner JA, Chakravarti A: Waardenburg syndrome and Hirschsprung disease: evidence for pleiotropic effects of a single dominant gene. Am J Med Genet 35:100-104 (1990).

-Bonnet JP, Till M, Edery P, Attie T, Lyonnet S: Waardenburg-Hirschsprung disease in two sisters: a possible clue to the genetics of this association? Eur J Pediatr Surg 6:245-248 (1996).

Bottani A, Xie YG, Binkert F, Schinzel A: A case of Hirschsprung disease with a chromosome 13 microdeletion, $\operatorname{del}(13)(\mathrm{q} 32.3 \mathrm{q} 33.2)$ : potential mapping of one disease locus. Hum Genet 87:748-750 (1991).

Ceccherini I, Zhang AL, Matera I, Yang G, Devoto $\mathrm{M}$, et al: Interstitial deletion of the endothelin-B receptor gene in the spotting lethal (sl) rat. Hum Mol Genet 4:2089-2096 (1995).

-Fidlerová H, Senger G, Kost M, Sanseau P, Sheer D: Two simple procedures for releasing chromatin from routinely fixed cells for fluorescence in situ hybridization. Cytogenet Cell Genet 65:203-205 (1994).

-Florijn RJ, Bonden LAJ, Vrolijk H, Wiegant J, Vaandrager JW, et al: High-resolution DNA fiber-FISH for genomic DNA mapping and colour bar-coding of large genes. Hum Mol Genet 4:831-836 (1995).

-Gariepy CE, Cass DT, Yanagisawa M: Null mutation of endothelin receptor type $\mathrm{B}$ gene in spotting lethal rats causes aganglionic megacolon and white coat color. Proc Natl Acad Sci USA 93:867-872 (1996).

-Heng HH, Tsui LC: High resolution free chromatin/DNA fiber fluorescent in situ hybridization. J Chromatogr A 806:219-229 (1998).

- Hosoda K, Hammer RE, Richardson JA, Baynash AG, Cheung JC, et al: Targeted and natural (piebald-lethal) mutations of endothelin-B receptor gene produce megacolon associated with spotted coat color in mice. Cell 79:12671276 (1994).

Hultgren BD: Ileocolonic aganglionosis in white progeny of overo spotted horses. J Am Vet Med Assoc 180:289-292 (1982).
Iannuzzi L, Di Berardino D: Tools of the trade: diagnostic and research applied to domestic animal cytogenetics. J Appl Genet 49:357-366 (2008).

Iannuzzi L, Di Meo GP, Perucatti A, Schibler L, Incarnato D, Cribiu EP: Comparative FISH mapping in river buffalo and sheep chromosomes: assignment of forty autosomal type I loci from sixteen human chromosomes. $\mathrm{Cy}$ togenet Cell Genet 94:43-48 (2001).

ISCNDB (2000) International System for Chromosome Nomenclature of Domestic Bovids. Di Berardino D, Di Meo GP, Gallagher DS, Hayes H, Iannuzzi L (eds). Cytogenet Cell Genet 92:283-299 (2001).

Lamont MA, Fitchett M, Dennis NR: Interstitial deletion of distal $13 \mathrm{q}$ associated with Hirschsprung's disease. J Med Gen 26:100104 (1989).

Lühken G, Fett K, Pauciullo A, Huisinga A, Erhardt G: Familiar hypopigmentation syndrome in sheep associated with homozygous deletion of the entire endothelin type-B receptor gene. PLoS One 7:e53020 (2012).

McCabe L, Griffin LD, Kinzer A, Chandler M, Beckwith JB, McCabe ER: Overo lethal white foal syndrome: equine model of aganglionic megacolon (Hirschsprung disease). Am J Med Genet 36:336-340 (1990).

Metallinos DL, Bowling AT, Rine J: A missense mutation in the endothelin-B receptor gene is associated with Lethal White Foal Syndrome: an equine version of Hirschsprung disease. Mamm Genome 9:426-431 (1998).

Nicodemo D, Coppola G, Pauciullo A, Cosenza G, Ramunno L, et al: Chromosomal expression and localization of aphidicolin-induced fragile sites in standard karyotype of river buffalo (Bubalus bubalis). Cytogenet Genome Res 120:178-182 (2008).

Omenn GS, McKusick VA: The association of Waardenburg syndrome and Hirschsprung megacolon. Am J Med Genet 3:217-223 (1979).

Pauciullo A, Fett K, Lühken G, Parma P, Di Berardino D, Erhardt G: A cytogenetic investigation on the lethal white syndrome in sheep. Abstract 20th International Colloquium on Animal Cytogenet and Gene Mapping (ICACGM), pp 77-78 Córdoba, April, (2012a).
Pauciullo A, Nicodemo D, Cosenza G, Peretti V, Iannuzzi A, et al: Similar rates of chromosomal aberrant secondary oocytes in two indigenous cattle (Bos taurus) breeds as determined by dual-color FISH. Theriogenology 77:675683 (2012b).

Perry GH, Dominy NJ, Claw KG, Lee AS, Fiegler $\mathrm{H}$, et al: Diet and the evolution of human amylase gene copy number variation. Nature Genet 39:1256-1260 (2007).

Ramunno L, Cosenza G, Rando A, Illario R, Gallo $\mathrm{D}$, et al: The goat as1-casein gene: gene structure and promoter analysis. Gene 334:105111 (2004).

-Santschi EM, Purdy AK, Valberg SJ, Vrotsos PD, Kaese H, Mickelson JR: Endothelin receptor $\mathrm{B}$ polymorphism associated with lethal white foal syndrome in horses. Mamm Genome 9: 306-309 (1998).

Schläpfer J, Gallagher DS, Burzlaff JD, Davis SK, Taylor JF, Womack JE: Physical mapping of the endothelin receptor type B to bovine chromosome 12. Mamm Genome 8:380-381 (1997).

Schneider JE, Leipold HW: Recessive lethal white in foals. J Eq Med Surg 2:479-482 (1978).

Shah KN, Dalal SJ, Desai MP, Sheth PN, Joshi NC, Ambani LM: White forelock, pigmentary disorder ofirides, andlongsegment Hirschsprung disease: possible variant of Waardenburg syndrome. J Pediatr 99:432-435 (1981)

Shanske A, Ferreira JC, Leonard JC, Fuller P, Marion RW: Hirschsprung disease in an infant with a contiguous gene syndrome of chromosome 13. Am J Med Gen 102:231-236 (2001).

Svetlova EY, Razin SV, Debatisse M: Mammalian recombination hot spot in a DNA loop anchorage region: a model for the study of common fragile sites. J Cell Biochem 81:170-178 (2001).

Trommershausen-Smith A: Lethal white foals in matings of overo spotted horses. Theriogenology 8:303-311 (1977).

Vonderfecht SL, Bowling AT, Cohen M: Congenital intestinal aganglionosis in white foals. Vet Pathol 20:65-70 (1983).

Wallace AS, Anderson RB: Genetic interactions and modifier genes in Hirschsprung's disease. World J Gastroenterol 17:4937-4944 (2011).

-Yang GC, Croaker D, Zhang AL, Manglick P, Cartmill T, Cass D: A dinucleotide mutation in the endothelin-B receptor gene is associated with lethal white foal syndrome (LWFS); a horse variant of Hirschsprung disease. Hum Mol Genet 7:1047-1052 (1998). 